\title{
Potential of Wood Ash as a Fertilizer in BRS Piatã Grass Cultivation in the Brazilian Cerrado Soil
}

\author{
Edna Maria Bonfim-Silva ${ }^{*}$, Marcel Thomas Job Pereira1, Tonny José Araújo Da Silva ${ }^{1}$, \\ William Fenner ${ }^{2}$
}

${ }^{1}$ Department of Agricultural and Environmental Engineering, Institute of Agricultural Sciences and Technology (ICAT), Federal University of Mato Grosso (UFMT), Cuiabá, Brazil

${ }^{2}$ Faculty of Agronomy and Zootechnic (FAAZ), Post Graduating in Tropical Agriculture, Federal University of Mato Grosso (UFMT), Cuiabá, Brazil

Email:*embonfim@hotmail.com

How to cite this paper: Bonfim-Silva, E.M., Pereira, M.T.J., Da Silva, T.J.A. and Fenner, W. (2017) Potential of Wood Ash as a Fertilizer in BRS Piatã Grass Cultivation in the Brazilian Cerrado Soil. American Journal of Plant Sciences, 8, 2333-2344. https://doi.org/10.4236/ajps.2017.810156

Received: August 8, 2017

Accepted: September 1, 2017

Published: September 4, 2017

Copyright $\odot 2017$ by authors and Scientific Research Publishing Inc. This work is licensed under the Creative Commons Attribution International License (CC BY 4.0).

http://creativecommons.org/licenses/by/4.0/

\begin{abstract}
Utilizing wood ash as a fertilizer in agriculture is a viable alternative to the soil nutrients absorbed by the crops. The aim of this study was to assess the phytometric and productive features of Brachiaria brizantha (cv. BRS Piatã) fertilized with wood ash in the Brazilian Cerrado. The experiment was performed in a greenhouse, adopting a completely randomized design, and applying five rates of wood ash $\left(0,5,10,15\right.$ and $\left.20 \mathrm{~g} \cdot \mathrm{dm}^{-3}\right)$ with five replicates. The shoot plant parts were subjected to three successive cuts 30 -day intervals each. The results were submitted to the analysis of variance and regression analysis at $5 \%$ probability. The wood ash rates between 13 to $17 \mathrm{~g} \cdot \mathrm{dm}^{-3}$ clearly produced the best results for plant height $(102.24,84.42$ and $63.27 \mathrm{~cm})$, leaf/stem ratio (1.61, 1, 78 and 1.94), and chlorophyll index (46.66, 41.93 and 38.39), respectively, during the first, second and third evaluations. A $94 \%$ increase in the shoot dry mass ( $2^{\text {nd }}$ and $3^{\text {rd }}$ evaluations) and root parts was noted for the wood ash rate of $20 \mathrm{~g} \cdot \mathrm{dm}^{-3}$, compared with the treatment involving wood ash fertilization. Wood ash affects the phytometric features, increases the chlorophyll concentration and thus the BRS Piatã grass production in the Oxisol of the Brazilian Cerrado.
\end{abstract}

\section{Keywords}

Solid Residue in Agriculture, Tropical Grass, Brachiaria brizantha, Alternative Fertilizer

\section{Introduction}

Ranked among of the principal production systems of the world, pastures ac- 
count for around $70 \%$ of arable land [1], and are regarded as very important in several temperate and tropical zones [2]. Brazil, possesses nearly 200 million of hectares of edaphoclimatic conditions and native and cultivated pastures [3], mainly the Brachiaria grasses.

Genus Brachiaria has contributed significantly to Brazil, as it enabled cattle ranching on the acidic and poorly fertility, and the basis of the cultivated pastures in the country [4].

The arable areas frequently show soils with quality disparity, revealing nutritional deficits that arise from intense and constant cultivation. Therefore, the soil fertility is normally corrected by applying chemical fertilizers, obtained from non-renewable sources, and which in turn affect the production costs. Hence, certain measures and alternatives need to be established to maintain the systems on a long-term basis and wood ash is one such alternative source [5].

Considering this, cattle ranchers require alternative and cheaper means of soil fertilization, without adversely affecting either the environment or grazing animals. Wood ash appears to rank high among the suitable options for agricultural crops, as it offers a vital means of recovering some of the nutrients lost through soil leaching and crop utilization. Wood ash is composed of a series of elements essential for plants and, as it is alkaline, it changes the soil $\mathrm{pH}$, which is an important criterion for its implementation in agriculture [6].

As a good option, reusing wood ash can minimize commercial fertilizer requirements, which in turn will reduce soil acidification and raise the calcium reserves [7]. Utilization of plant waste in agriculture is a good practice that has increased production and alleviated issues of solid waste disposal. From this perspective, using the ash as a fertilizer can prove to be a sustainable alternative supply of $\mathrm{P}$ to the agricultural systems [8]. As it is versatile in nature, wood ash can be utilized along with liquid waste, to boost its nutrient supply [9].

Brazil has the enormous potential for generating energy through thermochemical conversion, produces enormous quantities of waste (ash) that must ultimately be disposed. One of the ways could be their application to pastures used for grazing, and for the recovery of degraded areas. However, scientific proof is necessary for the correct application of the wood ash [10].

The aim of this study was to assess the productive and phytometric characteristics of Brachiaria brizantha (cv. BRS Piatã) in response to the application of wood ash rates to the Brazilian Oxisol.

\section{Material and Methods}

The experiment was conducted in a greenhouse at the Federal University of Mato Grosso, Campus of Rondonópolis-MT, Brazil, using the forage grass, genus Brachiaria brizantha cv. BRS Piatã.

The soil was first collected at a depth of $0.00-0.20 \mathrm{~m}$ from a region supporting Cerrado vegetation, classified as Oxisol [11]. The chemical and granulometric analysis of the soil was done according to and the results are seen in Table 1 [12]. 
Table 1. Chemical and granulometric analysis of Oxisol at $0.00-0.20 \mathrm{~m}$ layer.

\begin{tabular}{cccccccccccc}
\hline \multicolumn{2}{c}{$\mathrm{pH}$} & $\mathrm{P}$ & $\mathrm{K}$ & $\mathrm{Ca}$ & $\mathrm{Mg}$ & $\mathrm{H}$ & $\mathrm{Al}$ & $\mathrm{SB}$ & $\mathrm{CEC}$ & $\mathrm{V}$ & $\mathrm{O} . \mathrm{M}$. \\
\hline water & $\mathrm{CaCl}_{2}$ & \multicolumn{2}{c}{$\mathbf{m g} \cdot \mathrm{dm}^{-3}$} & & $\mathrm{cmol}_{\mathrm{c}} \cdot \mathrm{dm}^{-3}$ & & $\mathrm{cmol}_{\mathrm{c}} \cdot \mathrm{dm}^{-3}$ & $\%$ & $\mathbf{g} \cdot \mathrm{dm}^{-3}$ \\
\hline 4.9 & 4.2 & 1.1 & 29 & 0.6 & 0.3 & 5.7 & 0.5 & 1 & 7.3 & 13.5 & 28.7 \\
\hline
\end{tabular}

SB-Base Sum; CEC—Cation Exchange Capacity; V—Base Saturation; O. M.-Organic Matter.

The wood ash used, from a food industry boiler, had $\mathrm{pH}$ around 10.4 and was characterized as fertilizer (Table 2).

The completely randomized design was adopted for the experiment, comprising five rates of wood ash, with five replicates. The wood ash was applied in rates of $0,5,10,15$ and $20 \mathrm{~g} \cdot \mathrm{dm}^{-3}$. Each experimental plot included a plastic pot of 5 $\mathrm{dm}^{-3}$ soil capacity. The wood ash became integrated into the soil, remaining there for a 30-day incubation period.

After the soil was incubated with the wood ash, sowing was done at about 2.5 $\mathrm{cm}$ depth. Germination began five days after sowing. The plants were thinned once the plants achieved $10 \mathrm{~cm}$ height, according to the criteria of size, homogeneity and arrangement within the pots, leaving only five plants per pot (Figure 1).

After irrigating the plants by the gravimetric method, soil moisture was maintained at $60 \%$ of the maximum water retention capacity. Nitrogen fertilization, using urea as a nitrogen source, was done in the experimental plots at the recommended rates of $200 \mathrm{mg} \cdot \mathrm{dm}^{-3}$, in three applications (the first performed at the time of the plant thinning, the second and third after each successive cut).

The phytometric characteristics were evaluated by performing three cuts at each 30-day interval, assessing the plant height and leaf/stem ratio, as well as the productive characteristics, shoot and root dry masses.

The chlorophyll index was checked every 30 days before to each cutting, at which 10 readings were recorded per experimental unit on the recently expanded diagnostic sheets $(+1$ and +2$)$ (Figure 2), taking the average reading for each pot. The readings were done avoiding the leaf ribs, ensuring they were under suitable light intensity conditions.

At the time the plants were cut, the plant heights from the soil to the tip of the forage canopy were recorded using a graduated scale, and the average plant heights per pot were noted.

After each of the three cuttings, the plant material was harvested and weighed and the tiller and leaf masses were separately estimated. They were packed in paper bags and subjected to forced-air drying at $65^{\circ} \mathrm{C}$ for 72 hours until constant mass was achieved.

At the third cutting of the grass, apart from recording the dry mass of the aerial plant parts, the plant roots were collected. They were separated from the shoot using scissors and washed under running water, through a $1.00 \mathrm{~mm}$ sieve to eliminate the soil. 
Table 2. Chemical composition of wood ash.

\begin{tabular}{|c|c|c|c|c|c|c|c|c|c|}
\hline $\mathrm{pH}\left(\mathrm{CaCl}_{2}\right)$ & $\mathrm{P}_{2} \mathrm{O}_{5}$ & $\mathrm{~K}_{2} \mathrm{O}$ & $\mathrm{Ca}$ & $\mathrm{Mg}$ & $S$ & B & $\mathrm{Fe}$ & Mn & $\mathrm{Zn}$ \\
\hline \multicolumn{10}{|c|}{$\mathrm{g} \cdot \mathrm{kg}^{-1}$} \\
\hline 10.4 & 28.8 & 40.0 & 23.1 & 12.2 & 2.6 & 0.2 & 25.2 & 0.3 & 0.1 \\
\hline
\end{tabular}

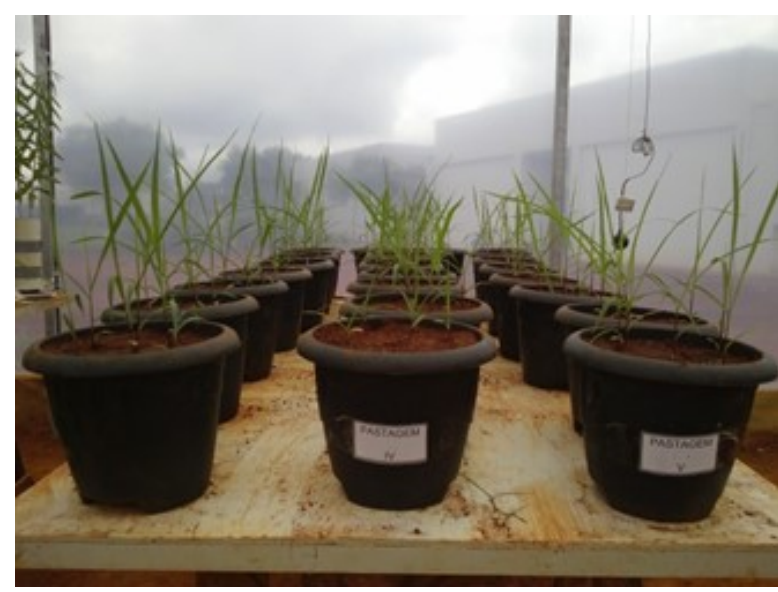

Figure 1. Piatã grass (Brachiaria brizantha) twelve days after sowing.

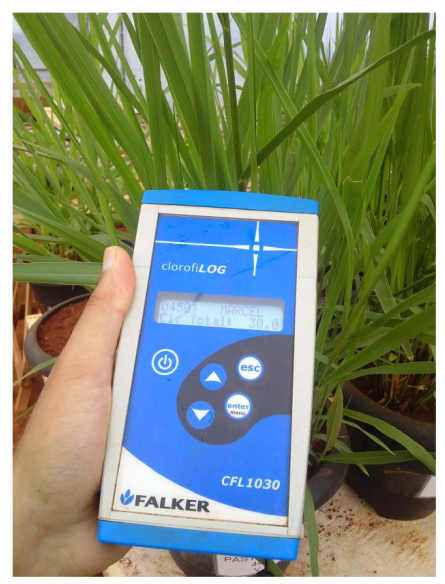

(a)

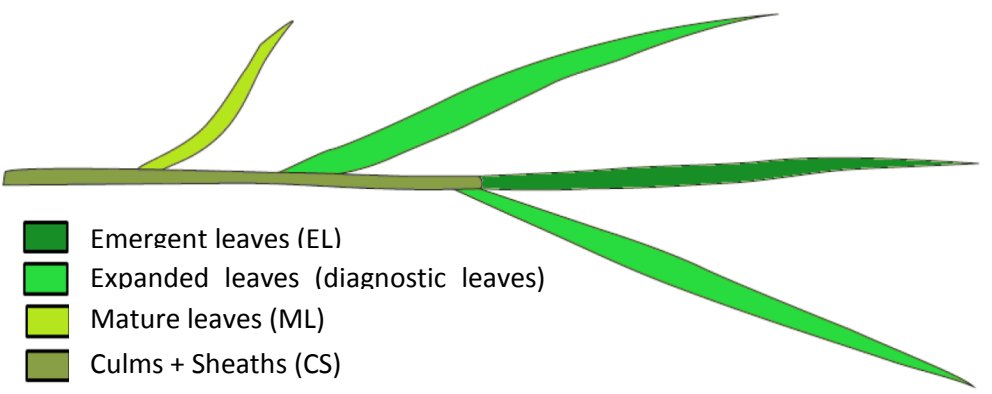

(b)

Figure 2. Employing the Clorofi LOG the chlorophyll index was read in the newly expanded leaf blades of Brachiaria brizantha cv. BRS Piatã (a); Scheme showing the separation of the aerial parts of Piatã grass (b). Source: Adapted from Lange (2007). 
The findings were then submitted to the analysis of variance by the F test and, when significant, regression analysis was done at 5\% error probability. Statistical analyses were performed using the SISVAR statistical program [13].

\section{Results and Discussion}

The chlorophyll index was adjusted to the quadratic model of regression, for all the three cuttings of the Piatã grass, revealing the degree of correction and fertilization the wood ash made to the soil. After the first and second cuts, the wood ash doses that induced the maximum readings were 13.10 and $13.99 \mathrm{~g} \cdot \mathrm{dm}^{-3}$, corresponding to the chlorophyll indices of 46.66 and 41.93, respectively. After the third cut, the wood ash rate of $17.91 \mathrm{~g} \cdot \mathrm{dm}^{-3}$ was found to induce the highest chlorophyll index of 38.39 (Figure 3).

The provision of $\mathrm{Fe}$ and $\mathrm{Mg}$ as soil nutrients, via fertilization using the wood ash, may have affected the plant chlorophyll index, as these nutrients are vital to the composition of this structure and biological nitrogen fixation. $\mathrm{Mg}$, besides being structurally a part of the chlorophyll molecule, is also a cofactor in the ATP hydrolysis, supplying energy for fixing the atmospheric $\mathrm{N}_{2}$ [14]. The Fe acts on the nitrogenase protein complex, producing Fe-protein and molybdenum-iron-protein, which in the presence of ATP, catalyzes the reduction of atmospheric nitrogen to ammonia [15].

Wood ash as fertilizer supplied an appreciable amount of potassium to the plants, as potassium enhances the activation of the enzymes responsible for nitrogen assimilation, protein synthesis and synthesis of leaf starch [16]. In this context, the combined rates of nitrogen and potassium induced a higher shoot dry mass and chlorophyll concentration in the greenhouse raised leaves [17].

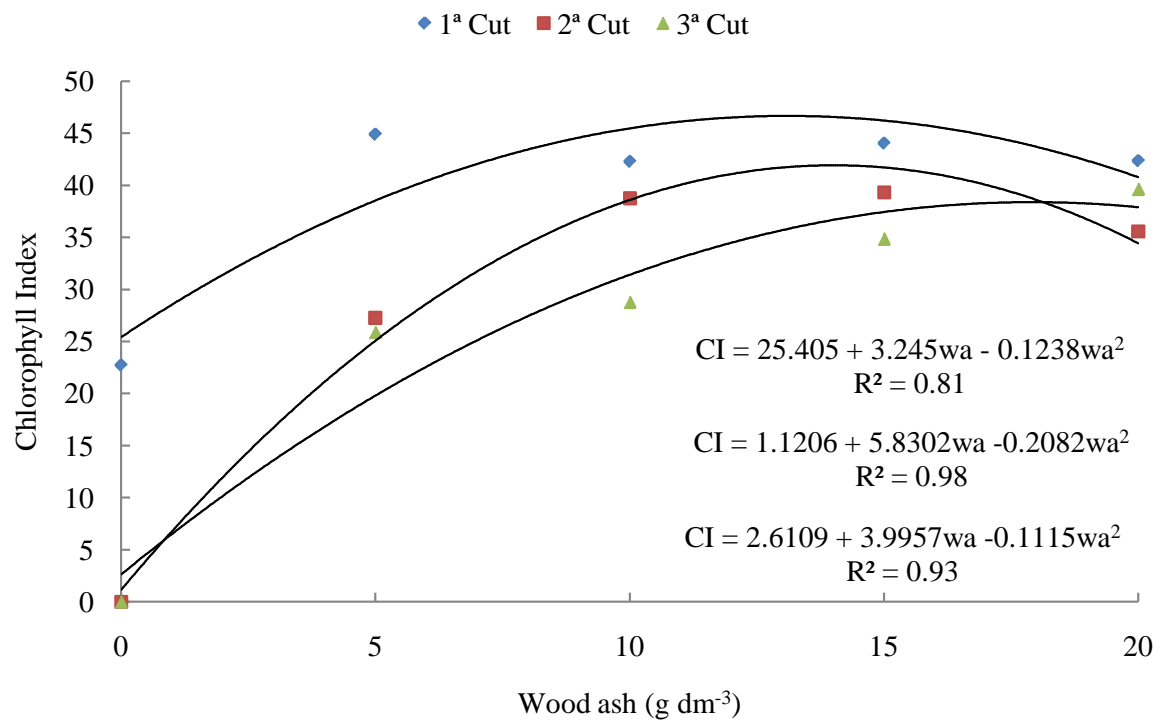

Figure 3. Chlorophyll index at the first, second and third cuts of Brachiaria brizantha cv. BRS Piatã, as result of wood ash rates in the Oxisol. CI = Chlorophyll Index; Wa = Wood ash. 
Researches involving the assessment of the effect of the applying wood ash on the chlorophyll index of Brachiaria brizantha cv. Marandu, showed an increase in the chlorophyll concentration [18]. The application of wood ash as fertilizer in the tropical forage grasses, confirmed an improvement in the expression of the structural characteristics and raised the chlorophyll indices of the Marandu and Xaraés grasslands that had been cultivated in the Cerrado of Mato Grosso State [19].

A $1 \%$ significance was noted for plant height among the different wood ash rates, adjusted to the quadratic model of regression in the first, second and third cuts (Figure $4(\mathrm{a})$ ). For the first cut, the $12.72 \mathrm{~g} \cdot \mathrm{dm}^{-3}$ rate induced the maximum

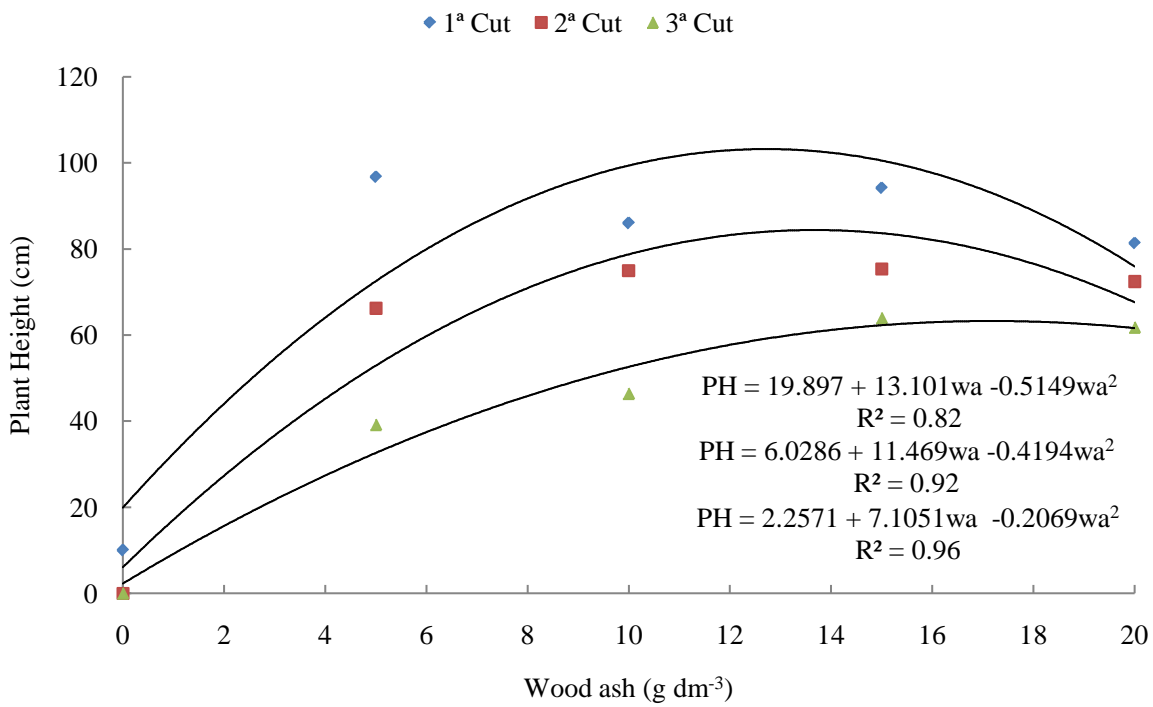

(a)

- $1^{\text {a }}$ Cut $\backsim 2^{\mathrm{a}}$ Cut $\Delta 3^{\mathrm{a}}$ Cut

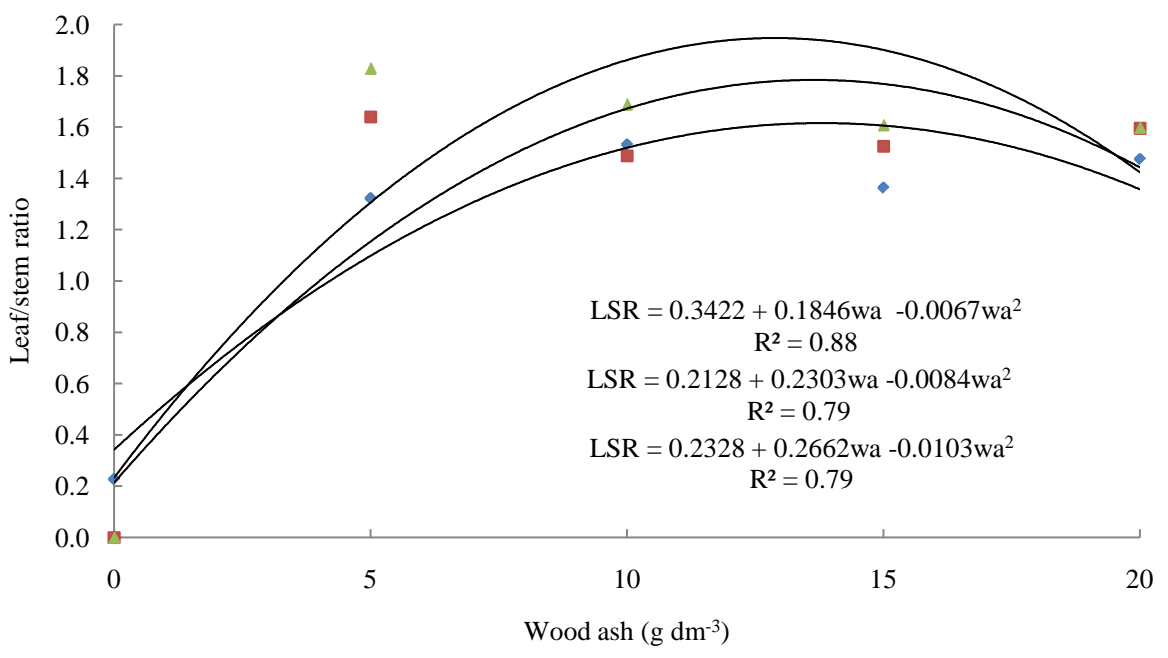

(b)

Figure 4. Plant height (a) and leaf/stem ratio (b) in the first, second and third cuts of Brachiaria brizantha cv. BRS Piatã, in response to the wood ash rate in the Oxisol. $\mathrm{PH}=$ Plant Height; LSR = Leaf/Stem Ratio; Wa = Wood ash. 
height $(102.24 \mathrm{~cm})$ in the Piatãgrass, showing an $80.54 \%$ increase, compared with the treatment that was not fertilized with the wood ash.

In the case of the second cutting, the wood ash dose of $13.42 \mathrm{~g} \cdot \mathrm{dm}^{-3}$ induced maximum plant height $(84.42 \mathrm{~cm})$, producing a $92.86 \%$ increase compared with the treatment that lacked the addition of wood ash.

The third and final cutting of the plants, the $17.17 \mathrm{~g} \cdot \mathrm{dm}^{-3}$ rate produced the maximum plant height $(63.27 \mathrm{~cm})$, a $96.44 \%$ increase when compared with the shortest plant height in the treatment without the addition of wood ash (witness).

The rates that induced the maximum heights for each cut were slowly increased at each stage of growth, while this structural feature got minimized. This could possibly be ascribed to the residual effect of the wood ash fertilization. However, no reapplication of this residue was visible in the second and third cuttings of this grass. Identical results were noted in a research in which the residual effect of the application of wood ash on the structural features of Brachiaria brizantha (Marandu and Xaraés cultivars) was visible [19].

Grass height, among others, is a significant feature that was evaluated to assess the productive potential of these grasses. Plant height is regarded as a structural characteristic, pertinent for adopting adequate management [20].

In all the three cuts performed, the leaf/stem ratio was adjusted to the quadratic regression model. The $13.0 \mathrm{~g} \cdot \mathrm{dm}^{-3}$ rate was found to induce the highest results, achieving 1.61, 1.78 and 1.94 leaf/stem ratio, respectively, for the first, second and third cuts (Figure 4(b)).

At all the three cuts, the leaf/stem ratio in the control treatment was notably below the minimum ratio considered the critical (ratio $=1)$ [21]. However, in all the three cuts, the leaf/stem ratio of the grasses was greater than 1, when the lowest wood ash rate $\left(5 \mathrm{~g} \cdot \mathrm{dm}^{-3}\right)$ was applied to the soil, revealing the benefits of correcting and fertilizing the soil using this residue.

A $1 \%$ significance of probability was selected to produce the shoot dry mass in all the three cuts. In the first cut, the shoot dry mass was adjusted to the quadratic regression model, recording maximum yield (31.72 g), with the addition of a rate of $16.35 \mathrm{~g} \cdot \mathrm{dm}^{-3}$ of wood ash (Figure 5).

For the second and third cuts of the forage grass, the shoot dry mass was adjusted to a linear regression model, in which increments higher than $94 \%$ were noted, within the range under study. This included making a comparison of the treatment supplied with the maximum rate $\left(20 \mathrm{~g} \cdot \mathrm{dm}^{-3}\right)$ with the control treatment (with no wood ash application).

The response to the quadratic model of the dry mass of the Piatã grass shoots is warranted, as the rate that induced the highest yield $\left(16.65 \mathrm{~g} \cdot \mathrm{dm}^{-3}\right)$ was responsible for providing $296.65 \mathrm{mg} \cdot \mathrm{dm}^{-3}$ of phosphorus. In fact, the phosphorus rates for the maximum yield of Piatã grass cultivated in the Oxisol are in the range of 189 - $304 \mathrm{mg} \cdot \mathrm{dm}^{-3}$ [22].

The linear response, evident in the second and third growth phases, can thus be ascribed to the reduction in the phosphorus concentration in the soil, although no fertilization using wood ash had been done to the soil. 
- $1^{\text {a Cut }}-2^{\text {a Cut }} \Delta 3^{\text {a Cut }}$

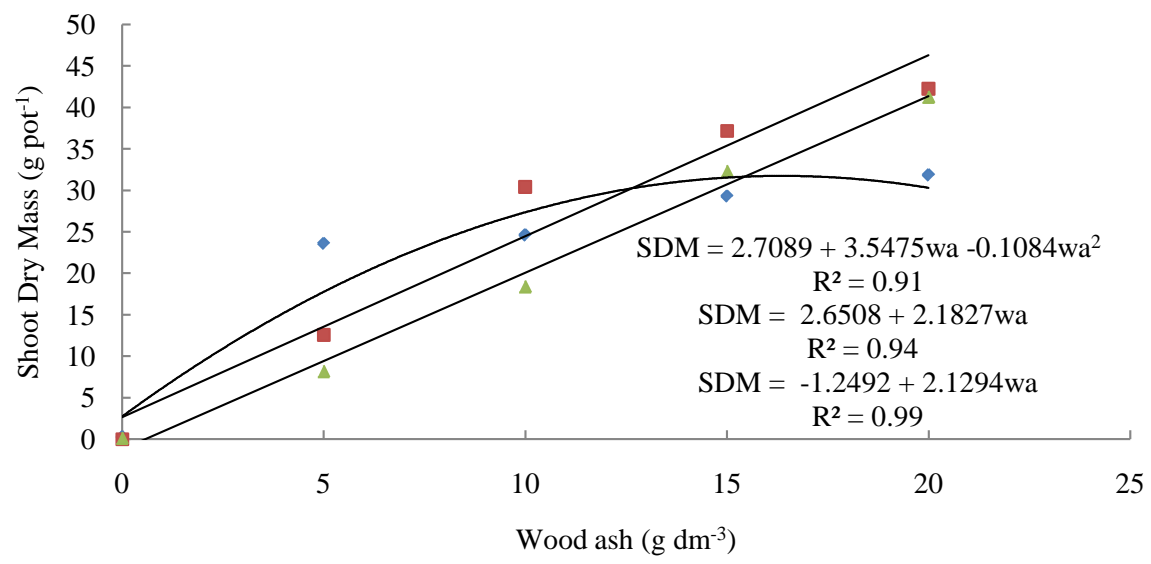

(a)

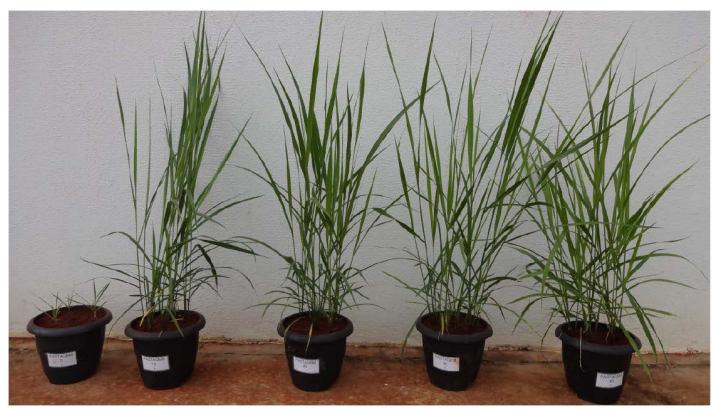

(b)

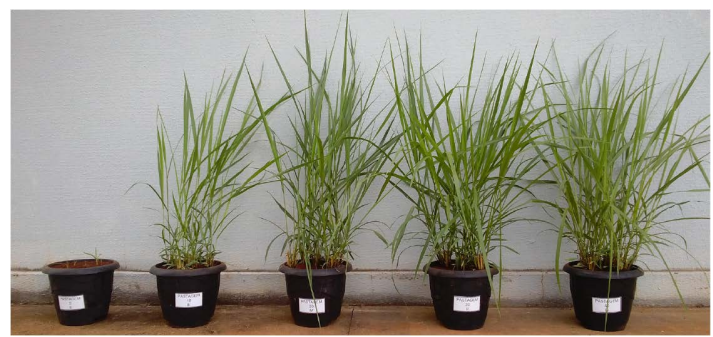

(c)

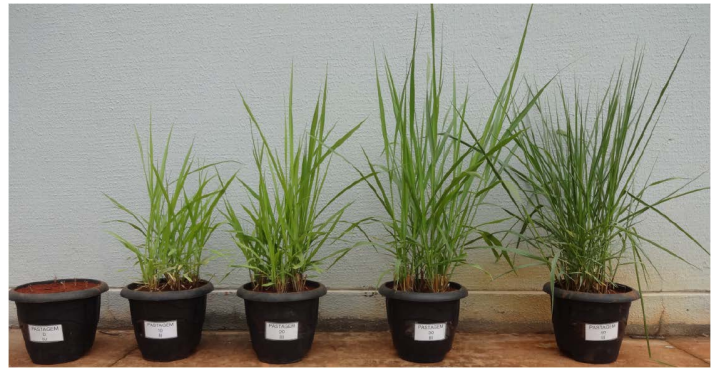

(d)

Figure 5. Shoot dry mass at the first, second and third cuts (a) of Brachiaria brizantha cv. BRS Piatã, in response to wood ash rates in the Oxisol. Shoot dry mass at the first (b), second (c) and third cuts (d). SDM = Shoot Dry Mass; Wa = Wood ash.

From several research papers, it is evident that various crops exhibited a growth and production increase in the field and greenhouse experiments. Grasses 
like oats (Avena sativa L.), wheat (Triticum aestivum L.), maize (Zea mays L.), as well as a few legumes such as beans (Phaseolus vulgaris L.) and soybean (Glycine $\max$ L.) showed a biomass increase after wood ash application. Such yield increases were attributed mostly to the additional provision of $\mathrm{K}, \mathrm{P}$ and $\mathrm{B}$, present in the ash [23]. Generally, when wood ash was applied, the acidic properties of the soils were affected, which resulted in increased crop productivity [24]. Study with Ultisol and Oxisol in Brazil reported that the greater increases on production of Marandu grass were obtained at $15 \mathrm{~g} \cdot \mathrm{dm}^{-3}$ of wood ash [25], corroborating with results of this research and evidencing the potential of wood ash on crop production.

The root dry mass was adjusted to the linear regression model, with a $94 \%$ increased yield, in the range analyzed (Figure 6). Notably, the phosphorus encourages faster root growth and plant development by raising the water efficiency, as it affects the root development and tillering in grasses, particularly during the implantation stage [22].

Therefore, considering the resulting maximum yield produced in this study interval, the wood ash probably contained an inadequate concentration of this nutrient, thus highlighting the need for a longer experimental interval.

Wood ash has been frequently reported to be used as a fertilizer. Post burning, appreciable quantities of $\mathrm{P}, \mathrm{Ca}, \mathrm{Mn}$ and $\mathrm{Mg}$ (about 75\%) have been confirmed in the residue [26]. The application of wood ash for the growth of tropical plants is advantageous as it minimizes the $\mathrm{Al}$ and $\mathrm{Mn}$ toxicity, besides supplying the plants with nutrients [27]. The authors also emphasized already in that time for the care with due to the nutrient imbalance in the soil correction was necessary by the addition of supplements, mainly those of N, P and $\mathrm{K}$.

The main limitations for use of wood ash in large fields it is the transport of ash from industries until farm for application on soil and the creation of culture

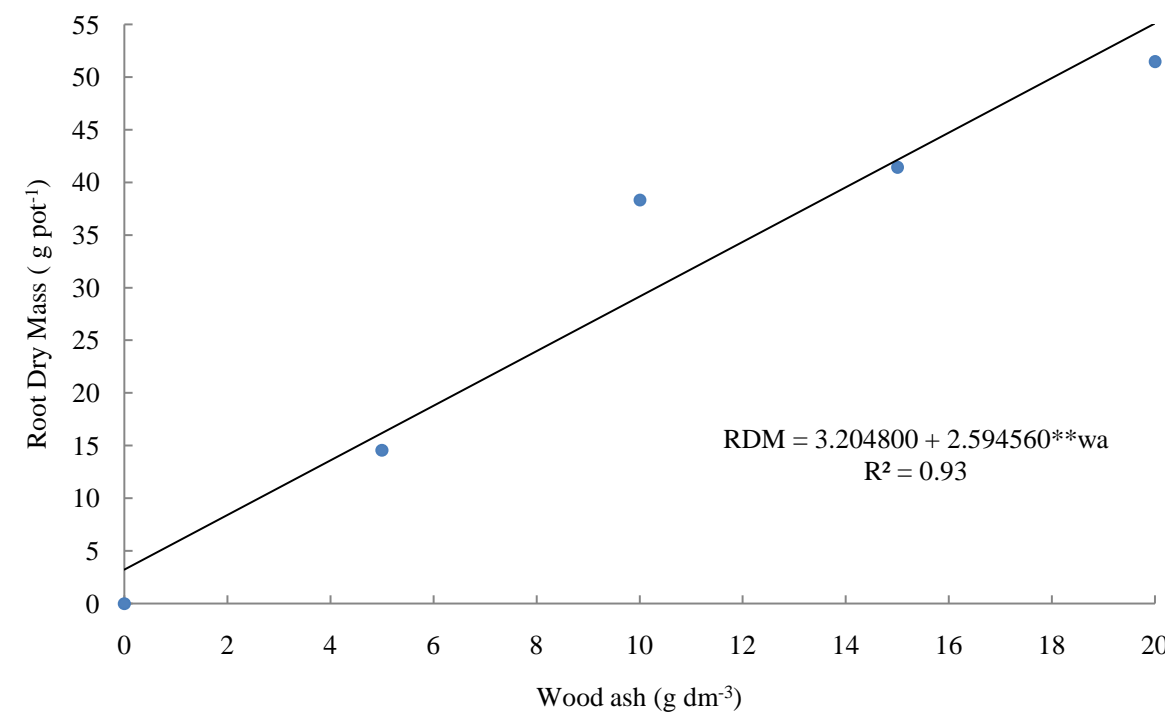

Figure 6. Root dry mass of Brachiaria brizantha cv. BRS Piatã, in response to the wood ash rate in the Oxisol. $\mathrm{RDM}=$ Root Dry Mass; Wa = Wood ash. 
to use of alternative fertilizers. The higher rates of wood ash necessary for the better effects on crop development are other challenge to consolidation of use the wood ash in the agriculture.

\section{Conclusion}

The wood ash applied in 13 and $17 \mathrm{~g} \cdot \mathrm{dm}^{-3}$ rates, positively affects the phytometric characteristics and the chlorophyll index of Brachiaria brizantha (cv. BRS Piatã) in the Brazilian Cerrado Oxisol. The productive characteristics of the Piatã grass were evident with the wood ash dosage of $16 \mathrm{~g} \cdot \mathrm{dm}^{-3}$, which facilitated the maximum yields during the first growth stage. During the second and third growth stages of the forage grass, fertilization with wood ash rates produced linear responses indicating the necessity to restore the level of soil fertility as the plants absorb and transport the nutrients via the aerial parts, at each cutting.

\section{Acknowledgements}

The authors extend their gratitude to the Brazilian National Council for Scientific and Technological Development $(\mathrm{CNPq})$ and Coordination for the Improvement of Higher Education Personnel (CAPES) for providing them with scholarships.

\section{References}

[1] Dubeux Jr., J.C.B., Muir, J.P., Santos, M.V.F., Vendramini, J.M.B., Mello, A.C.L. and Lira, M.A. (2011) Improving Grassland Productivity in the Face of Economic, Social, and Environmental Challenges. Revista Brasileira de Zootecnia, 40, 280-290.

http://www.revista.sbz.org.br/busca/index.php?chave=Improving+grassland+productiv ity + in + the + face + of + economic $\% 2 \mathrm{C}+$ social $\% 2 \mathrm{C}+$ and +environmental+challenges\&anonum=1991-1\&ano-num2=2016-9\&pt=1\&en=1\&area $=0$ \&palchave $=1 \&$ titulo $=1$ \&resum $\mathrm{o}=1$ \&autor $=1$

[2] Braga, G.J. (2010) Sequestro de carbono em pastagens cultivadas. Pesquisa e tecnologia, 7, 1-6.

http://www.aptaregional.sp.gov.br/acesse-os-artigos-pesquisa-e-tecnologia/edicao-201 0/2010-janeiro-junho/765-sequeestro-de-carbono-em-pastagens-cultivadas/file.html

[3] Costa, K.A.T., Faquin, V. and Oliveira, I.P. (2010) Doses e fontes de nitrogênio na recuperação de pastagens do capim-marandu. Arquivo Brasileiro de Medicina Veterinária e Zootecnia, 62, 192-199.

http://www.scielo.br/pdf/abmvz/v62n1/v62n1a26.pdf

https://doi.org/10.1590/S0102-09352010000100026

[4] Valle, C.B., Euclides, V.P.B. and Macedo, M.C.M. (2000) Características das plantas forrageiras do gênero Brachiaria. SimpósiosobreManejo da Pastagem, Piracicaba, 65-108.

[5] Arbestain, M.C., Saggar, S. and Leifeld, J. (2014) Environmental Benefits and Risks of Biochar Application to Soil. Agriculture, Ecosystems and Environment, 1, 1-4. https://doi.org/10.1016/j.agee.2014.04.014

[6] Reimann, C., Ottesena, R.T., Anderssona, M., Arnoldussenb, A., Kollerc, F. and Englmaier, P. (2008) Element Levels in Birch and Spruce Woodashes-Green Energy? Science of Total Environment, 393, 191-197.

https://doi.org/10.1016/j.scitotenv.2008.01.015 
[7] Zimmermann, S. and Frey, B. (2002) Soil Respiration and Microbial Properties in an Acid Forest Soil: Effects of Wood Ash. Soil Biology \& Biochermistry, 1, 1-11. https://doi.org/10.1016/S0038-0717(02)00160-8

[8] Cruz-Paredes, C., López-García, A., Rubaek, G.H., Hovmand, M.F., Sorensen, P. and Kjoller, R. (2016) Risk Assessment of Replacing Conventional P Fertilizers with Biomass Ash: Residual Effects on Plant Yield, Nutrition, Cadmium Accumulation and Mycorrhizal Status. Science of Total Environment, 1, 1-9.

https://doi.org/10.1016/j.scitotenv.2016.09.194

[9] Insam, H., Franke-Whittle, I.H., Knapp, B.A. and Plank, R. (2009) Use of Wood Ash and Anaerobic Sludge for Grassland Fertilization: Effects on Plants and Microbes. Die Bodenkultur, 60, 39-51.

https://diebodenkultur.boku.ac.at/volltexte/band-60/heft-2/insam.pdf

[10] Rocha, E.P.A., Gomes, F.J.B., Sermyagina, E., Cardoso, M. and Colodette, J.L. (2015) An Analysis of Brazilian Biomass Focusing on Thermochemical Conversion for Energy Production. Energy \& Fuels, 1, 1-39. https://doi.org/10.1021/acs.energyfuels.5b01945

[11] Empresa Brasileira de Pesquisa Agropecuária EMBRAPA (2013) Sistema brasileiro de classificação de solos. EMBRAPA, Brasília.

[12] Empresa Brasileira de Pesquisa Agropecuária EMBRAPA. (1997) Manual de métodos de análises de solo. Centro Nacional de Levantamento e Conservação do Solo. Embrapa Solos, Rio de Janeiro.

[13] Ferreira, D.F. (2011) Sisvar: A Computer Statistical Analysis System. Ciência e Agrotecnologia, 35, 1039-1042. https://doi.org/10.1590/S1413-70542011000600001

[14] Malavolta, E., Vitti, G.C. and Oliveira, S.A. (1997) Avaliação do estado nutricional das plantas: Princípios e aplicações. Potafós, Piracicaba.

[15] Kim, J. and Rees, D.C. (1994) Nitrogenase and Biological Nitrogen Fixation. Biochemistry, 33, 389-397. https://www.ncbi.nlm.nih.gov/pubmed/8286368 https://doi.org/10.1021/bi00168a001

[16] Meurer, E.J. (2006) Potássio. In: Fernandes, M.S., Ed., Nutrição mineral de plantas, Sociedade Brasileira de Ciência do solo, Viçosa, 281-299.

[17] Viana, E.M. and Kiehl, J.C. (2010) Doses de nitrogênio e potássio no crescimento do trigo. Bragantia, 69, 975-982. https://doi.org/10.1590/S0006-87052010000400024

[18] Bonfim-Silva, E.M., Cabral, C.E.A., Silva, T.J.A., Moreira, J.C.F. and Carvalho, J.C.S. (2013) Cinza vegetal: Características produtivas e teor de clorofila do capim-Marandu. Bioscience Journal, 29, 1215-1225. http://www.seer.ufu.br/index.php/biosciencejournal/article/view/15073/13015

[19] Bonfim-Silva, E.M., Santos, C.C. and Silva, T.J.A. (2015) Wood Ash Fertilization on Structural Characteristics and Chlorophyll Index of Tropical Forage Grasses. American Journal of Plant Sciences, 6, 1341-1348. https://doi.org/10.4236/ajps.2015.69133

[20] Hernández, G.A., Matthew, C. and Hodgson, J. (1997) Effect of Spring Grazing Management on Perennial Ryegrass and Ryegrass-White Clover Pastures 2. Tiller and Growing Point Densities and Population Dynamics. New Zealand Journal of Agricultural Research, 40, 37-50. https://doi.org/10.1080/00288233.1997.9513228

[21] Pinto, J.C., Gomide, J.A. and Maestri, M. (1994) Dry Matter Production and Leaf/Stem of Tropical Forage Grasses Grown in Pots, with Two Levels of Nitrogen. Revista Brasileira de Zootecnia, 23, 313-326.

[22] Rezende, C.G.B. (2013) Fosfato natural na adubação do capim Piatã em Latossolo 
Vermelho do Cerrado. Ms.D. Dissertation, Universidade Federal de Mato Grosso, Rondonópolis.

[23] Demeyer, A., Nkana, J.C.V. and Verloo, N.G. (2001) Characteristics of Wood Ash and Influence on Soil Properties and Nutrient Uptake: An Overview. Bioresource Technology, 77, 287-295.

[24] Mbah, C.N., Nwite, J.N., Njoku, C. and Nweke, I.A. (2010) Response of Maize (Zea mays L.) to Different Rates of Wood-Ash Application in Acid Ultisol in Southeast Nigeria. African Journal of Agricultural Research, 5, 580-583.

[25] Bezerra, M.D.L, Bonfim-Silva, E.M., Silva, T.J.A., Sousa, H.H.F., Duarte, T.F., Santo, E.S.E. and Pacheco, A.B. (2016) Wood Ash on the Fertilization of Marandu Grass in Brazilian Cerrado Soils. African Journal of Agricultural Research, 11, 1504-1510. https://doi.org/10.5897/AJAR2015-10729

[26] Ingerslev, M., Skov, S., Sevel, L. and Pedersen, L.B. (2011) Element Budgets of Forest Biomass Combustion and Ash Fertilization e a Danish Case-Study. Biomass Bioenergy, 35, 2697-2704.

[27] Nkana, J.C.V., Demeyer, A. and Verloo, M.G. (1998) Chemical Effects of Wood Ash on Plant Growth in Tropical Acid Soils. Bioresource Technology, 63, 251-260.

Submit or recommend next manuscript to SCIRP and we will provide best service for you:

Accepting pre-submission inquiries through Email, Facebook, LinkedIn, Twitter, etc. A wide selection of journals (inclusive of 9 subjects, more than 200 journals)

Providing 24-hour high-quality service

User-friendly online submission system

Fair and swift peer-review system

Efficient typesetting and proofreading procedure

Display of the result of downloads and visits, as well as the number of cited articles

Maximum dissemination of your research work

Submit your manuscript at: http://papersubmission.scirp.org/

Or contact ajps@scirp.org 